\title{
Nauczanie kierowane jako metoda rozwijająca samodzielność oraz autonomię dzieci i młodzieży z głęboką niepełnosprawnością intelektualną
}

\begin{abstract}
Beata Cytowska, Nauczanie kierowane jako metoda rozwijajaca samodzielność oraz autonomię dzieci i młodzieży z głęboką niepetnosprawnością intelektualną [Conductive education as a method of developing self-reliance and autonomy of children and young people with profound intellectual disabilities]. Interdyscyplinarne Konteksty Pedagogiki Specjalnej, nr 12, Poznań 2016. Pp. 61-83. Adam Mickiewicz University Press. ISSN 2300-391X
\end{abstract}

The purpose of this article is to show the possibility of using conductive education system and its effectiveness in working with children and young people with profound intellectual disabilities attending rehabilitation - educational groups, in order to develop and form their self-reliance, and the grounds of autonomy.

In the first part of text the author described the functioning of people with profound intellectual disabilities, pointing to their specific difficulties in the field of independent functioning. Then author showed the assumptions of conductive education system with regard to the objectives set by The Ministry of Education for rehabilitation-educational classes.

Using of the possibilities inherent in the monographic method, the author presented rehabilitation-educational activities with the use of conductive education method, with particular attention to the aspects of the development of autonomy of children and young people with profound intellectual disabilities. The data for analysis and description was collected through the observation (direct, participatory and indirect - by video camera) of participants of rehabilitation - educational activities (15 persons), analysis of documentation (observation sheets and individual 
curriculums) and interviews with teachers of three rehabilitation - educational groups.

Although it is difficult to determine the actual impact of Petö method on increase of self-reliance and autonomy of children and young people with profound intellectual disabilities, the collected information indicates the importance of the conductive education method - particularly in aspects of socialization, communication and agility.

Key words: profound intellectual disability, rehabilitation - educational groups, conductive education - method of Petö, self-reliance, autonomy

Osoby z głębokim stopniem niepełnosprawności intelektualnej stanowią nieliczną populację, bowiem zaledwie ok. $1 \%^{1}$ grupy doświadczającej niepełnosprawności intelektualnej. W Polsce do jej określania używa się również terminu "głęboka wieloraka niepełnosprawność", wprowadzonego przez Andreasa Fröhlicha, niemieckiego autora publikacji Stymulacja od podstaw ${ }^{2}$. Według przywołanego autora określenie to oznacza skrajne trudności we wszystkich aspektach życia, niezależnie od dziedziny. Osoby nią dotknięte żyją na pograniczu tego, co w naszych stosunkach międzyludzkich uważane jest jeszcze za normalne, ograniczenia odnoszą się do wszystkich możliwości. Jej (osoby) rozwój emocjonalny, poznawczy i fizyczny jest wyraźnie ograniczony lub zniekształcony. To samo dotyczy zachowań społecznych i umiejętności porozumiewania się ${ }^{3}$.

$\mathrm{W}$ polskim systemie oświaty osoby z orzeczoną głęboką niepełnosprawnością intelektualną objęte są obowiązkiem szkolnym realizowanym w ramach zajęć rewalidacyjno-wychowawczych. W niniejszym opracowaniu oba terminy - głęboka wieloraka nie-

1 Za: I. Chrzanowska, Pedagogika specjalna. Od tradycji do wspótczesności, Oficyna Wydawnicza „Impuls”, Kraków 2015, s. 271.

2 A. Fröhlich, Stymulacja od podstaw. Jak stymulować rozwój osób głęboko wielorako niepetnosprawnych, WSiP, Warszawa 1998.

3 Ibidem, s. 11. 
pełnosprawność i głęboka niepełnosprawność intelektualna - używane są zamiennie.

Najczęstszą przyczyną wyjątkowo utrudnionego codziennego funkcjonowania wspomnianej populacji są zmiany neurologiczne powstałe na skutek organicznych uszkodzeń centralnego układu nerwowego, do których może dojść pod wpływem traumatycznych czynników prenatalnych, perinatalnych i postnatalnych. Owe uszkodzenia prowadzą do dysfunkcji całego układu nerwowego, także narządów zmysłów, dlatego w omawianej grupie przeważają jednostki z zaburzeniami sprzężonymi, np. niepełnosprawność intelektualna w najcięższej postaci współwystępuje z niepełnosprawnością ruchową, wzrokową lub słuchową. Stąd używanie określenia głęboka wieloraka niepełnosprawność jest ze wszech miar uzasadnione.

Typowym zespołem objawów o podłożu organicznym łączącym ze sobą niniejsze zaburzenia jest mózgowe porażenie dziecięce (mpd) i zdecydowana większość osób z głęboką niepełnosprawnością intelektualną pierwotnie doznała mpd. Kolejna grupa przyczyn ma zgoła inny charakter, gdyż wiąże się z czynnikami genetycznymi, a wśród nich wyróżnić można wrodzone wady rozwojowe dotyczące centralnego układu nerwowego, które pojawiają na skutek nieprawidłowości w przekazie genetycznym od rodziców lub nabytych w trakcie zapłodnienia przez różnego typu zaburzenia chromosomalne ${ }^{4}$.

Osoby z poważnie zakłóconym funkcjonowaniem centralnego układu nerwowego kumulują energię życiową na przezwyciężanie defektów rozwojowych, ograniczeń i szoku poporodowego zamiast wykorzystywać ją do aktywności poznawczej. Przez słabszą mobilność własną lub jej brak mają ograniczony dopływ wrażeń i doświadczeń. Ponadto mogą mieć trudność z przystosowaniem się do

${ }^{4}$ B. Cytowska, A. Drzazga, Znaczenie i wykorzystanie komunikacji wspomagajacej $i$ alternatywnej (AAC) w porozumiewaniu się z osobami z głęboka niepetnosprawnościa intelektualna, [w:] Dzieci o specjalnych potrzebach komunikacyjnych. Diagnoza - edukacja - terapia, red. B. Winczura, Oficyna Wydawnicza „Impuls”, Kraków 2013, s. 340; A. Jankiewicz, D. Skrypnik, K. Skrypnik, Głęboka niepetnosprawność intelektualna a rozwój emocjonalno-społeczny i motoryczny, „Psychiatria” 2014, tom 11, nr 4, s. 223. 
warunków życia, a niepowodzenia adaptacyjne sprzyjają ich wycofywaniu się z różnych działań. Koncentracja energii na utrzymaniu elementarnej homeostazy, a także niesatysfakcjonujące lub wręcz traumatyczne doświadczenia kontaktów z otoczeniem zewnętrznym, wyzwalają silne reakcje lękowe, powstrzymują gotowość do eksploracji otoczenia i tłumią ciekawość 5 .

Funkcjonowanie psychomotoryczne osób z głęboką wieloraką niepełnosprawnością nie wykracza poza wczesny okres rozwoju, według określenia Piageta, sensoryczno-motoryczny. Poważne ograniczenia ruchowe i problemy z percepcją skutkują ciągłą zależnością od pomocy i opieki drugiej osoby, dlatego też jednostki te mają kłopoty z wyodrębnieniem siebie z otoczenia, co nie sprzyja rozwojowi tożsamości. Osoba, która nie odróżnia „ja” od „nie-ja” słabo rozumie siebie i swoje potrzeby, dlatego potrzebuje bliskości fizycznej, aby dostrzec innych, aby doświadczyć bodźców z otoczenia, by nawiązać kontakt ze swoim środowiskiem i czuć się zrozumianą bez słów ${ }^{6}$.

Przytoczona krótka charakterystyka podłoża głębokiej wielorakiej niepełnosprawności oraz funkcjonowania osób nią dotkniętych wskazuje na duże utrudnienia tej grupy dzieci i młodzieży w uzyskiwaniu nawet podstawowego zakresu samodzielności oraz związanej z nią autonomii. Dlatego praca rewalidacyjno-wychowawcza z rozpatrywaną populacją wymaga ciągłego poszukiwania metod, które pozwolą na wydobycie potencjału tkwiącego w uczniach, jednak z pełnym zrozumienie ich potrzeb.

W odniesieniu do zarysowanej problematyki celem niniejszego artykułu jest ukazanie możliwości wykorzystania systemu nauczania kierowanego, a także jego skuteczności, w pracy z dziećmi i młodzieżą uczęszczającymi do zespołów rewalidacyjno-wychowawczych po to, by kształtować i rozwijać ich samodzielność, a tym samym zręby autonomii.

System nauczania kierowanego (ang. Conductive Education Petö) był i jest określany mianem modelu zintegrowanego jakościo-

${ }^{5}$ M. Kościelska, Oblicza upośledzenia, PWN, Warszawa, s. 186-190.

${ }^{6}$ A. Fröhlich, op. cit., s. 15. 
wo procesu rehabilitacji i edukacji. Jego twórcą był Andreas Petö (1893-1967) - lekarz i pedagog, człowiek o wszechstronnych zainteresowaniach. Kontynuatorką działalność Petö była Maria Hári, która między innymi stworzyła system przygotowania nauczycieli/przewodników.

Przed II wojną światową Petö prowadził liczne badania i publikował swoje wyniki, które stanowiły podwaliny systemu nauczania kierowanego. W 1947 r. w Budapeszcie podjął próby zastosowania opracowanej metody w Kolegium Pedagogiki Specjalnej na grupie 13 dzieci. Ta działalność dała początek Państwowemu Instytutowi Terapii Ruchowej założonemu w 1950 r. w Budapeszcie. Od 1968 r. na Węgrzech szkoły i instytucje ochrony zdrowia mają obowiązek zgłaszania do rejestru Instytutu każdego dziecka z zaburzeniami ruchowymi ${ }^{7}$.

Od 1986 r. następuje umiędzynarodowienie nauczania kierowanego, które staje się coraz bardziej popularne w Ameryce Północnej, Europie Zachodniej, Japonii, Izraelu, Austrii, Nowej Zelandii, Libanie, Chinach, a także od początku lat 90. XX w. w Polsce.

System nauczania kierowanego opiera się na trzech zasadach ${ }^{8}$ :

- dziecko/osoba stanowi nierozłączną całość - fizyczną, intelektualną i emocjonalną - będącą w ciągłym procesie zmiany i rozwoju. Akcentuje się holistyczne ujęcie człowieka i dynamikę jego rozwoju;

- nauczanie kierowane jest kompleksowym systemem, który podlega ciągłej zmianie;

- teorie wyjaśniające ten kompleksowy system powinny być na bieżąco aktualizowane.

Celem głównym całościowego modelu jest postrzeganie osoby z perspektywy jej możliwości uczenia się i nabywania umiejętności

${ }^{7}$ J. Forrai, History of a Special Healing Method for Motordisordered Children: Conductive Education, Communicationes de Historia Artis Medicinae, Suplement: 200-2001, 2007.

${ }^{8}$ F. Beck, Remembering András Pető, 2nd International Conference for Theory and Practice in Education, http://www.tsadkadima.org.il/_Uploads/dbsAttached Files/Remebering_Peto(3).pdf [20.05.2016]. 
przystosowawczych zgodnie z aktualnym stanem, a nie skupienie się na problemie jednostki i dążenie do jego korygowania. Petö nadał kierunek zmiany myślenia w procesie rewalidacyjnym: od dysfunkcji do ortofunkcji ${ }^{9}$.

Sedno systemu stanowią trzy elementy: jego filozofia, proces i metoda.

Petö opracowując system nauczania kierowanego, studiował osiągnięcia wybitnych naukowców, badaczy i twórców teorii/koncepcji, które dały naukowe podwaliny filozofii ${ }^{10}$ :

- uczenie się przez aktywny, bezpośredni kontakt z rzeczywistością - z teorii Johanna H. Pestalozzi,

- satysfakcjonująca interakcja przynosi korzyści wszystkim jej uczestnikom - zgodnie z koncepcją Jacoba Moreno,

- aktywowanie dziecka następuje przez interakcje społeczne w kontekście kulturowym - z teorii Lva Vygotskiego,

- najistotniejsze narzędzia w edukacji to dialog i komunikacja z rozważań Martina Bubera

- rozwój wyższych funkcji umysłowych zależy od przekazywania społecznych znaczeń za pomocą języka, w praktykach społecznych - z teorii Aleksandra Łurji,

- korzystny wpływ grupy na jednostkę, na jej samodzielność, ma praktyka wychowania w samorządnych wspólnotach dziecięcych - z koncepcji Antona Makarenki,

- brak niezbędnych warunków do działania cofa aktywność do sekwencji prostych, niepowiązanych czynności - z teorii Alieksieja Leontieva,

- zabawa jako znacząca aktywność dziecka służy jego socjalizacji i przygotowuje go do pracy - teoria aktywności Sergieja Leonidowicza Rubinsteina.

${ }^{9}$ F. Beck, Remembering András Pető, 2nd International Conference for Theory and Practice in Education, http://www.tsadkadima.org.il/_Uploads/dbsAttached Files/Remebering_Peto(3).pdf [20.05.2016].

10 T. Gegenwarth (ed.), Handbook Conductive Education. Together, Constructive, Conductive - Adult learners in Complex Rehabilitation, European Association of Conductive Education and Professional Practice (ECA), 2012, s 23-24, http://www. movewalk.se/Portals/0/Handbook_Grundtvig_Final\%20Version.pdf [30.05.2016]. 
Biorąc pod uwagę założenia systemu i jego filozofię, należy przyznać, że tak stabilne, a zarazem elastyczne podwaliny stwarzają możliwość jej ciągłego rozwoju.

W procesie nauczania kierowanego znaczące są nierozłączne i równorzędnie traktowane następujące elementy ${ }^{11}$ :

- osoba z neurologicznym zaburzeniem (ang. the neurological impaired person),

- nauczyciel prowadzący (ang. the conductor),

- środowisko uczenia się (ang. the learning environment).

Proces nauczania kierowanego opiera się na następujących zasadach $^{12}$ :

- motywacji (wiele teorii wyjaśnia działanie motywacji, najpopularniejsze są teorie sytuujące motywację $\mathrm{w}$ odniesieniu do zaspokajania indywidualnych potrzeb np. M. Maslow, J. Rogers);

- intencji (to stan psychiczny, który daje moc działaniu, ukierunkowuje aktywność, np. koncepcja M. Schelera, podejście J. Ayres);

- uczeniu się przez działanie/ruch (motor learning theory), opiera się na plastyczności neurologicznej, a więc możliwości centralnego systemu neurologicznego do modyfikacji połączeń neurologicznych oraz zmian, dzięki prowadzeniu systematycznego uczenia się motorycznego (ruchowego), najlepsze efekty daje połączenie działania naprawczego $\mathrm{z}$ adaptacją i kompensacją $\mathrm{w}$ kierunku osiągnięcia jak najlepszego funkcjonowania osoby $\mathrm{w}$ pełnionych rolach $\mathrm{np}$. podejście H. Adamsa;

- kognitywizmie jako opozycji do behawioryzmu - człowiek nie jest zaprogramowany do odpowiedzi na bodźce płynące ze środowiska, jego działanie jest wynikiem racjonalnego ucznia się poprzez aktywne uczestnictwo np. teoria Vygotskyego, koncepcja Maturany;

11 Ibidem, s. 25.

12 Ibidem, s. 25-26. 
- społecznym uczeniu się - teoria rozsławiona przez Albert Bandura, stwierdza, że zachowania społeczne są wynikiem uczenia się przede wszystkim przez obserwację i naśladowanie działania innych. Zachowanie społeczne jest również nagradzane jako wynik naśladowania;

- przepływie (ang. the flow) - jest to stan psychiczny jednostki w trakcie działania, który polega na całkowitym skupieniu emocji i motywacji, co daje maksymalną energię do działania. Przez takie zanurzenie proces uczenia się i zmiany jest najefektywniejszy;

- modyfikowaniu struktur kognitywnych - koncepcja Feuersteina, która opiera się na ludzkiej wyjątkowej zdolności do modyfikowania struktur poznawczych w odpowiedzi na zmieniające się otoczenie w celu przystosowania się do owych zmian. Pomiędzy człowiekiem a środowiskiem dochodzi do dwóch typów interakcji odpowiadających za rozwój zróżnicowanych struktur poznawczych i wyższych procesów myślowych: uczenie się przez doświadczenie bezpośrednie, uczenie się pośredniczące (nauczyciel jako mediator, łącznik).

Sedno systemu nauczania kierowanego stanowi metodyka nauczania kierowanego, na którą składają się praktyczne składniki łączące przedstawioną wcześniej teorię z praktyką, należą do nich ${ }^{13}$ :

- prowadzący/nauczyciel - tworzy atmosferę (osobowość podnosząca), wzbudza motywację do działania, jest mediatorem/pośrednikiem w uczeniu się/doświadczaniu, jest empatyczny, traktuje dziecko podmiotowo, ma przygotowanie teoretyczno-praktyczne (studia, kursy, praktyki),

- grupa - rówieśnicy objęci podobnym programem nauczania, tak dobrani, żeby się wzajemnie motywowali, uczyli przez naśladownictwo,

- ułatwione prowadzenie (ang. conductive facilitation) - nauczyciel tzw. pierwszy prowadzący współpracuje z tzw. drugimi

13 Z. Zhang, A. Bowens, S. Bennet, Effectiveness of conductive education for cerebral palsy, Evidence Based Review, 2003, www.Conductive Education for Cerebral Palsy (PDF 292K) - October 2003 (1).pdf [10.05.2016]. 
prowadzącymi, którzy asystują dzieciom, wspierają ich czynności motoryczne i dbają o poprawność wykonania zadania, ułatwienia także poprzez specjalny sprzęt/wyposażenie sali (m.in. meble),

- seria zadań - cyklicznie powtarzające się zadania: na skrzynkach/boksach, na stołach, szkoła rąk, ubieranie się/rozbieranie się, przygotowywanie do wstawania, do chodzenia itp. Każde zadanie ma swoje ogniwa: rozpoczęcie - korekta postawy, powitanie, wyznaczenie celów dla każdego dziecka w trakcie wykonywanych zadań - w siadzie, leżeniu, staniu, zmianie pozycji; podsumowanie zajęć - ocena i samoocena, przyznanie nagród,

- rytmiczna intencja, inaczej metoda rytmiczności poleceń intencja, czyli polecenie nauczyciela, wypowiedziane $\mathrm{w}$ osobie pierwszej „ja” (dziecko/osoba), rytmiczność powtórzeń wpływa na skupienie i przepływ energii,

- codzienna rutyna - egzemplifikowana przez program i strukturę zajęć dająca poczucie bezpieczeństwa i przewidywalność działań, efektem codziennych ćwiczeń powinna być generalizacja i transfer,

- środowisko uczenia się (meble, pomoce, środowisko domowe współpraca z rodzicami, wyposażenie mieszkania),

- obserwacja prowadzącego (wnikliwa, korygowanie postawy i czynności).

Zajęcia rewalidacyjno-wychowawcze będące formą edukacji dzieci i młodzieży z niepełnosprawnością intelektualną w stopniu głębokim korespondują $\mathrm{z}$ metodą nauczania kierowanego przez spójność wyznaczonego im głównego celu: „rozwijanie zainteresowania otoczeniem oraz rozwijanie samodzielności w funkcjonowaniu w codziennym życiu, stosownie do ich możliwości psychofizycznych oraz indywidualnych potrzeb rozwojowych"14.

14 Rozporządzenie Ministra Edukacji Narodowej z dnia 23 kwietnia 2013 r. w sprawie warunków i sposobu organizowania zajęć rewalidacyjno-wychowaw- 
Zajęcia obejmująi5:

- naukę nawiązywania kontaktów w sposób odpowiedni do potrzeb i możliwości uczestnika zajęć,

- kształtowanie sposobu komunikowania się z otoczeniem na poziomie odpowiadającym indywidualnym możliwościom uczestnika zajęć,

- usprawnianie ruchowe i psychoruchowe w zakresie dużej i małej motoryki, wyrabianie orientacji w schemacie własnego ciała i orientacji przestrzennej,

- wdrażanie do osiągania optymalnego poziomu samodzielności w podstawowych sferach życia,

- rozwijanie zainteresowania otoczeniem, wielozmysłowe poznawanie otoczenia, naukę rozumienia zachodzących w nim zjawisk, kształtowanie umiejętności funkcjonowania w otoczeniu,

- kształtowanie umiejętności współżycia w grupie,

- naukę celowego działania dostosowanego do wieku, możliwości i zainteresowań uczestnika zajęć oraz przejawianej przez niego aktywności.

Dotychczasowe badania nad zastosowaniem nauczania kierowanego w szeroko pojętej rehabilitacji dzieci i młodzieży z mpd wyprowadziły dwie konkluzje.

Pierwsza związana z badaniami skuteczności metody w rehabilitacji ruchowej wskazała, że nie ma istotnej różnicy pomiędzy efektami rehabilitacji z zastosowaniem nauczania kierowanego i innych metod fizjoterapeutycznych przeznaczonych dla dzieci takich jak metoda Vojty czy Bobath ${ }^{16}$.

czych dla dzieci i młodzieży z upośledzeniem umysłowym w stopniu głębokim (Dz.U. z 7 maja 2013, poz. 529).

15 Ibidem.

16 Z. Zhang, A. Bowens, S. Bennet dokonali przeglądu artykułów, w których przedstawiono badania dotyczące efektów stosowania nauczania kierowanego w pracy z dziećmi z mózgowym porażeniem dziecięcym. Autorzy w jednej z konkluzji wskazali, że z przytoczonych wyników badań wynika, iż dzieci prowadzone nauczaniem kierowanym osiągały podobne wyniki jak te, które poddane były in- 
Druga, związana z długotrwałą obserwacją stosowania metody Petö w codziennej, systematycznej pracy $\mathrm{z}$ tą grupą dzieci, ujawnia jednak jej potencjał terapeutyczny i edukacyjny ${ }^{17}$.

$\mathrm{W}$ artykule chciałabym się odnieść do drugiego wniosku, jednak $\mathrm{w}$ aspekcie pracy z grupą dzieci i młodzieży z głęboką niepełnosprawnością intelektualną.

Podstawą do prowadzenia dalszej analizy jest materiał audiowizualny zebrany $\mathrm{w}$ ciągu ostatnich 4 lat $\mathrm{w}$ placówce, do której uczęszczają dzieci i młodzież z głęboką wieloraką niepełnosprawnością oraz obserwacje zajęć prowadzonych nauczaniem kierowanym. Nagrania zajęć były realizowane systematycznie 1-2 razy $\mathrm{w}$ roku szkolnym z 3 grupami dzieci i młodzieży w wieku od 10 do 22 lat, z zachowaniem podobieństwa wiekowego i aktywności, zaś obserwacje były prowadzone także 2 razy w roku szkolnym. Ponadto postępy $\mathrm{w}$ rozwoju dzieci były badane Inwentarzem PPAC Gunzburga $^{18}$ na koniec roku szkolnego (maj-czerwiec). Powstałe

nym programom terapeutycznym (bez nauczania kierowanego). Druga konkluzja wskazuje, że nauczanie kierowane nie przynosi większych efektów niż inne konwencjonalne metody rehabilitacyjne Z. Zhang, A. Bowens, S. Bennet, op. cit. Do podobnych wniosków doszli autorzy H. Anttila i in., Effectiveness of Physiotherapy and Conductive Education Interventions in Children with Cerebral Palsy: A Focused Review, „American Journal of Physical Medicine \& Rehabilitation” 2008, t. 87, nr 6.

${ }^{17} \mathrm{~B}$. Wądołowska, Kierowane nauczanie - edukacyjne rozwiazanie problemu medycznego, "Biuletyn sieci mpd” nr 4; http://www.spdn.pl/Biuletyny,a,32.html [10.05.2016]; J. Darrah, B. Watkins, L. Chen, C. Bonin, Effects of Conductive Education Intervention for Children with a Diagnosis of Cerebral Palsy, An AACPDM Evidence Report; http://www.aacpdm.org/UserFiles/file/conductive-education.pdf [20.05.2016].

18 Skala PPAC (ang. Primary Progress Assessment Chart - skala oceny postępów w nabywaniu umiejętności podstawowych) - narzędzie, które zostało opracowane przez H.C. Gunzburga w 1976 r. wykorzystywane do badania osób z niepełnosprawnością intelektualną $\mathrm{w}$ stopniu głębokim. Oceniane są $\mathrm{w}$ nim funkcje o charakterze społecznym: uspołecznienie, komunikacja, samodzielność (w zakresie spożywania posiłków, poruszania, korzystania z toalety i mycia się, ubierania i rozbierania się) oraz udział w zajęciach (sprawność manualna oraz zręczność kontrola motoryki). Inwentarz PPAC należy do podstawowych formularzy PAC jako jeden $\mathrm{z}$ trzech (pozostałe to PAC-1 do badania osób z umiarkowaną i znaczną niepełnosprawnością intelektualną, PAC-2 do badania osób z lekkim stopniem 
dokumenty diagnostyczne poddałam analizie w odniesieniu do indywidualnych programów zajęć tworzonych dla każdego uczestnika zespołu rewalidacyjno-wychowawczego. Uzupełniającą techniką były wywiady z nauczycielkami (6 osób), które prowadziły zajęcia zgodnie z metodą nauczania kierowanego. Wywiady miały charakter tematycznie ukierunkowany, gdyż głównie polegały na stawianiu pytań dotyczących efektywności stosowania metody Petö w odniesieniu do poszczególnych uczniów oraz całego zespołu.

Wykorzystane techniki oraz narzędzia pozwoliły na napisanie monografii działalności rewalidacyjno-wychowawczej z wykorzystaniem metody nauczania kierowanego, ze szczególnym zwróceniem uwagi na aspekty rozwijania samodzielności u dzieci i młodzieży z głęboką niepełnosprawnością intelektualną.

Tadeusz Pilch ${ }^{19}$ monografią nazwa metodę badań, której przedmiotem są instytucje wychowawcze w rozumieniu placówki lub instytucjonalne formy działalności wychowawczej, prowadzącą do gruntownego rozpoznania struktury, zasad i efektywności działań wychowawczych oraz opracowania koncepcji ulepszeń i prognoz rozwojowych. W swoim opracowaniu odwołam się do „instytucjonalnej formy działalności wychowawczej” jaką są zespoły rewalidacyjno-wychowawcze i ich efektywności w kontekście uzyskiwania coraz większego zakresu samodzielności wynikająca z połączenia oddziaływań rewalidacyjno-wychowawczych z metodą nauczania kierowanego. Zdaniem Jerzego Apanowicza w metodzie monograficznej uwzględnia się przede wszystkim informacje $\mathrm{w}$ formie jakościowo-opisowej. Służy ona naukowemu zgłębieniu wyodrębnionych cech i elementów jakościowych określonej struktury, systemu lub procesu, określenie ich charakteru, wielkości oraz scharaktery-

niepełnosprawności intelektualnej). Polska wersja, opracowana z uwzględnieniem realiów występujących w naszym kraju, ukazała się w 1980 r. jako wynik prac profesora Tadeusza Witkowskiego: Podręcznik do Inwentarza PPAC H.C. Gunzburga do oceny postępu w rozwoju społecznym (osób z upośledzeniem umysłowym), COMPWZ MEN, Warszawa 1988.

${ }_{19}$ T. Pilch, T. Bauman, Zasady badań pedagogicznych. Strategie ilościowe i jakościowe, Wydawnictwo ŻAK, Warszawa 2001, s. 75. 
zowaniu ich funkcjonowania i rozwoju ${ }^{20}$. Monografia pozwala na dokonanie dokładnego wglądu w to, co dzieje się w przedmiocie badań, np. skutki współdziałania wielu czynników i ich wpływu na proces kształtowania się danego przedmiotu lub występujące w nim zjawiska, wykrycie oraz opisanie typowych dla niego zdarzeń, występujących tendencji itp ${ }^{21}$. Jedynie badania mogą dostarczyć wiedzy o skomplikowanej strukturze i zmianach zachodzących w małych układach społecznych (jak np. gospodarstwie, rodzinie, wsi) ${ }^{22}$.

Głównym problemem badawczym w niniejszej pracy było pytanie: jakie efekty w sferze samodzielności i autonomii dzieci i młodzieży z głęboką niepełnosprawnością intelektualną przynosi codzienne stosowanie metody nauczania kierowanego w zespołowych zajęciach rewalidacyjno-wychowawczych?

Poddałam analizie 15 przypadków dzieci i młodzieży uczęszczających do 3 zespołów rewalidacyjno-wychowawczych. Uczestnicy pierwszej grupy to 6 dzieci w wieku 12-15 lat (wiek w momencie ostatniego badania), do drugiej grupy włączone są dzieci w podobnym wieku (obecnie mają 10-15 lat), zaś trzecią grupę tworzą starsi uczniowie obecnie w wieku 14-22 lat. Wszyscy mają orzeczoną niepełnosprawność intelektualną w stopniu głębokim.

$\mathrm{W}$ zespołach rewalidacyjno-wychowawczych zajęcia $\mathrm{z}$ wykorzystaniem metody nauczania kierowanego odbywają się codziennie. Są to sesje na skrzynkach lub na materacach. Każda z sesji ma swoje stałe ogniwa: powitanie, korekta postawy, przydzielenie celów do wykonania w trakcie ćwiczeń w leżeniu, siedzeniu, staniu, zmianie pozycji. Założenia metody oraz specyfika pracy z osobami z głęboką niepełnosprawnością intelektualną stanowią o potrzebie zachowania schematu dnia i stałej struktury zajęć.

20 J. Apanowicz, Metodologia ogólna, Bernardinum, Gdynia 2002, s. 67.

${ }^{21}$ J. Sztumski, Wstęp do metod i technik badań społecznych, Wydawnictwo Śląsk, Katowice 2005, s. 114-118.

22 J. Topolski, Problemy metodologiczne badań wsi, [w:] Badania empiryczne w socjologii, tom II, red. M. Malikowski, M. Niezgoda, Tyczyn 1997, s. 414. 
Poszczególne zajęcia mają swój temat przewodni, w którym kładzie się nacisk na komunikację. Niemal wszyscy uczniowie korzystają z metod AAC (ang. alternative and auxiliary communication alternatywnej i wspomagającej komunikacji). Tematyka zajęć jest zgodna z programem grupy i indywidualnymi programami zajęć (tworzonymi dla poszczególnych uczestników zespołu rewalidacyjno-wychowawczego). Ponadto nauczyciel prowadzący (konduktor) przygotowuje słownictwo wykorzystywane na zajęciach (nowe słowa, których symbolem są obrazki), w ten sposób rozbudowuje się u uczniów rozumienie języka.

Ćwiczenia ruchowe proponowane dzieciom i młodzieży są dostosowane do ich możliwości, dobierane są tak, aby mogły być przydatne w aktywności praktycznej: ubieraniu, rozbieraniu, jedzeniu, myciu itp. Na przykład ruchy wykonywane z zastosowaniem ringo czy szarfy symulują zakładanie kurtki, spodni, czapki, butów itp. Jest to zgodne z zasadą transferu, o której wcześniej pisałam, a która ma najistotniejsze znaczenie $\mathrm{w}$ kształtowaniu samodzielności podopiecznych. Od zabaw i zajęć z użyciem przedmiotów oraz przyborów zastępczych uczestnik uczy się ruchów i aktywności, które mogą zostać wykorzystane w trakcie działań samoobsługowych, nawet jeśli niewykonywanych samodzielnie (ze względu na poważne ograniczenia wynikające $\mathrm{z}$ porażenia mózgowego), to chociażby we współpracy z osobą pomagającą. Przykładem może być unoszenie bioder w leżeniu na materacu, żeby mógł pod nimi przetoczyć się drążek lub żeby rytmicznie podskakiwać do śpiewanej piosenki, zaś celem praktycznym jest pomaganie $\mathrm{w}$ trakcie przebierania pieluchy, ściągania spodni, bielizny itp.

Wspólne z koleżankami i kolegami uczestniczenie w zajęciach daje możliwość wzajemnego naśladowania podejmowanych aktywności, uczenia się współżycia i współgrania w grupie: czekania na swoją kolej, zauważania potrzeb drugiej osoby, podpowiadanie, pomaganie, zabieganie o uwagę nauczyciela prowadzącego.

Analiza nagrań zajęć oraz obserwacja uczestnicząca pozwoliły dostrzec ich podobieństwa i różnice. Podobieństwo zasadzało się na 
założeniach systemu nauczania kierowanego oraz potrzebach uczniów. Do wspólnych elementów można więc zaliczyć:

- stałość struktury zajęć: powitanie i pożegnanie w tym samym stylu (piosenka) oraz gest symbolizujący „witam was”, "zaczynamy zajęcia”, , koniec” i „dziękuję";

- zapowiedź kolejnych działań (za pomocą obrazka, gestu i słowa);

- korektę postawy w sesji na skrzynkach: trzymanie głowy prosto (żeby ringo nie spadało), kolana szeroko ustawione, zaś stopy płasko na podłodze, pokazywanie części ciała i stron lewej i prawej (w rytm piosenki) - te ćwiczenia mają na celu rozumienie swojego ciała, jego poszczególnych części oraz pozycji w przestrzeni;

- ćwiczenie wytrwałości w sesji stawania przy drabinkach: unoszenie się na nogach $\mathrm{z}$ siedzenia do stania $\mathrm{z}$ pokonywaniem poszczególnych szczebelków drabinki, korekta postawy z piosenką motywującą do utrzymania jak najdłużej pozycji stojącej z maksymalnym wyprostowaniem ciała, podniesieniem głowy;

- aktywność w sesji powitania na skrzynkach: rozpoznawanie swojej fotografii oraz koleżanek i kolegów (obecnych i nieobecnych), wybieranie spośród obecnych osoby, która będzie kontynuować czynność, wybieranie obrazka z zaobserwowaną pogodą, etykiety z dniem tygodnia, omówienie planu dnia - te elementy są zbieżne $z$ metodą ośrodków pracy częściej wykorzystywaną w edukacji dzieci i młodzieży z lekkim i umiarkowanym stopniem niepełnosprawności intelektualnej, celem tego typu zajęć jest poszerzanie wiedzy o najbliższym otoczeniu, uczenie umiejętności obserwowania, integracja grupy;

- aktywność w sesji na materacach (te zajęcia dotyczyły dwóch grup młodszych uczniów) wspólną częścią w obserwowanych zajęciach były ćwiczenia $\mathrm{z}$ drążkiem: podnoszenie ramion do góry w rytm piosenki, przekładanie drążka z ręki do ręki, toczenie go pod biodrami (najczęściej z pomocą dorosłego) - celem proponowanych aktywności było wzmocnienie mięśni kończyn oraz brzucha; 
- piosenki oraz rytmiczność zadań (np. „ja unoszę ręce wysoko, wysoko, wysoko...") - celem takiego postępowania jest przede wszystkim dążenie do płynności i celowości wykonywanych ruchów;

- rytmizowanie w imieniu dziecka - powtarzanie zadania rozpoczyna się od zaimka ,ja”, co ma podkreślić jego podmiotowość i sprawczość.

Elementy różnicujące zajęcia:

- różna tematyka (według pomysłów nauczycieli, jednak zgodna $z$ indywidualnymi programami zajęć i programem grupy),

- sposób realizacji niektórych zadań ukierunkowany na indywidualne możliwości podopiecznych,

- dynamika przebiegu lekcji uzależniona od cech osobowościowych nauczycielek i ich zaangażowania.

Analiza indywidualnych programów zajęć poszczególnych wychowanków oraz programów zajęć grupowych wykazała zgodność z celami stawianymi przez ustawodawcę we wcześniej cytowanym rozporządzeniu, także cele ogólne i operacyjne zamieszczone w konspektach obserwowanych zajęć są spójne z programami. Zaś same programy są pochodnymi wyników diagnozy za pomocą Inwentarza PPAC Gunzburga (wcześniej opisanego). W każdym ze wspomnianych aspektów - diagnostyczny, programowy i wykonawczy - wyodrębnić można cztery obszary: komunikacyjny (porozumiewanie się werbalne i alternatywne), poznawczy (rozwój percepcji oraz poszerzanie wiedzy o sobie i otaczającym świecie), ruchowo-motoryczny (rozwój motoryki dużej, małej, koordynacji ruchowej i lokomocji) oraz obejmujący samodzielność, sprawczość (samoobsługa w czynnościach codziennych, decydowanie w sytuacji wyboru).

Analiza kart obserwacyjnych Inwentarza PPAC z czterech lat (coroczna ocena postępów w rozwoju uczniów) wykazała w większości obszarów postęp (o zróżnicowanym zakresie). W tabeli poniżej ukazuję liczbowy zapis zadań wykonanych od pierwszego (rok szkolny 2011/2012) do czwartego badania (rok szkolny 2014/2015), obrazując w ten sposób progres w czterech ocenianych obszarach (zgodnie z przyjętym narzędziem), zaś poniżej tabeli dokonuję szczegółowej analizy. 


\begin{tabular}{|c|c|c|c|c|c|c|c|c|c|c|c|c|c|c|c|c|}
\hline \multirow{2}{*}{ 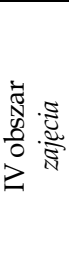 } & 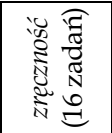 & 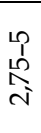 & $\begin{array}{l}a \\
\infty\end{array}$ & \begin{tabular}{l}
0 \\
1 \\
1 \\
\multirow{1}{1}{}
\end{tabular} & م̂ & $\mid \begin{array}{l}1 \\
1 \\
1 \\
1\end{array}$ & $\begin{array}{l}10 \\
10 \\
1 \\
\text { L }\end{array}$ & \begin{tabular}{c}
$n$ \\
\multirow{1}{1}{} \\
$\mathrm{I}$ \\
$\mathrm{N}$
\end{tabular} & $\mid \begin{array}{c}10 \\
o \\
1 \\
N\end{array}$ & 年 & 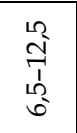 & $\begin{array}{l}\infty \\
1 \\
+\end{array}$ & $\stackrel{?}{1}$ & $\begin{array}{l}\infty \\
1 \\
1 \\
0 \\
0\end{array}$ & $\mid \begin{array}{l}1 \\
1 \\
1 \\
1 \\
10\end{array}$ & $\begin{array}{l}\infty \\
1 \\
\Lambda\end{array}$ \\
\hline & 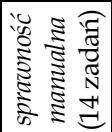 & $\begin{array}{l}0 \\
1 \\
1\end{array}$ & 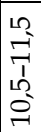 & 足 & $\begin{array}{l}12 \\
0 \\
1 \\
12 \\
10\end{array}$ & $\mid$\begin{tabular}{|c}
12 \\
10 \\
10 \\
10 \\
0
\end{tabular} & $\begin{array}{l}\hat{1} \\
\infty\end{array}$ & $\begin{array}{c}4 \\
1 \\
\text { I }\end{array}$ & $\begin{array}{c}10 \\
\sim \\
\Lambda \\
\sim\end{array}$ & $\mid \begin{array}{c}1 \\
12 \\
1 \\
1 \\
0 \\
0\end{array}$ & $\begin{array}{l}\text { Ln } \\
\infty \\
1 \\
10 \\
10\end{array}$ & $\begin{array}{l}0 \\
1 \\
1 \\
1\end{array}$ & $\begin{array}{l}0 \\
1 \\
\sim\end{array}$ & 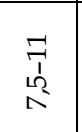 & $\begin{array}{l}0 \\
1 \\
1 \\
1\end{array}$ & $\begin{array}{l}a \\
\text { in } \\
\text { مै }\end{array}$ \\
\hline 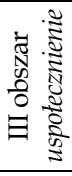 & 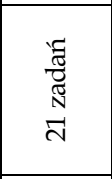 & $\begin{array}{l}\text { ñ } \\
\text { I } \\
\text { ñ } \\
\text { å }\end{array}$ & $\begin{array}{l}20 \\
2 \\
1 \\
1 \\
\infty \\
\infty \\
-1\end{array}$ & 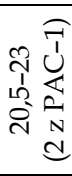 & $\stackrel{10}{\stackrel{1}{1}}$ & $\begin{array}{l}\infty \\
7 \\
1 \\
\end{array}$ & $\begin{array}{l}+1 \\
1 \\
1 \\
2 \\
\sigma\end{array}$ & $\begin{array}{l}10 \\
7 \\
10 \\
20 \\
2 \\
7\end{array}$ & $\frac{1}{7}$ & $\mid \begin{array}{c}m \\
n \\
1 \\
12 \\
-1 \\
-1\end{array}$ & $\begin{array}{l}20 \\
\stackrel{1}{7} \\
\text { م⿱ } \\
\text { के }\end{array}$ & $\begin{array}{l}\stackrel{ }{1} \\
1 \\
\infty \\
\sim\end{array}$ & $\begin{array}{l}m \\
\stackrel{n}{1} \\
\stackrel{1}{\sim}\end{array}$ & 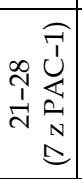 & $\begin{array}{l}\mathcal{N} \\
\stackrel{1}{1} \\
\stackrel{7}{-}\end{array}$ & 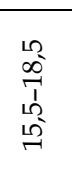 \\
\hline \multirow{2}{*}{ 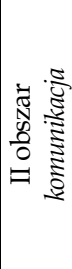 } & 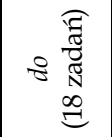 & $\begin{array}{l}n \\
\infty \\
n \\
1 \\
\stackrel{1}{2} \\
\stackrel{n}{n}\end{array}$ & $\begin{array}{l}0 \\
1 \\
1 \\
0 \\
0 \\
-1\end{array}$ & 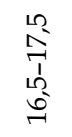 & 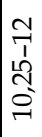 & 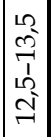 & 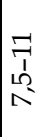 & $\begin{array}{l}0 \\
7 \\
1 \\
\alpha\end{array}$ & 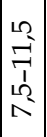 & $\left|\begin{array}{l}10 \\
1 \\
1 \\
\infty\end{array}\right|$ & 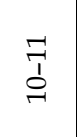 & $\begin{array}{l}10 \\
\stackrel{1}{1} \\
\infty \\
\end{array}$ & $\mid \begin{array}{l}12 \\
\infty \\
1 \\
1 \\
\infty \\
\infty \\
\infty\end{array}$ & $\begin{array}{l}\stackrel{m}{7} \\
\stackrel{1}{\longrightarrow}\end{array}$ & $\begin{array}{l}7= \\
71 \\
1 \\
\infty \\
\infty\end{array}$ & 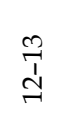 \\
\hline & 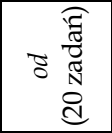 & $\begin{array}{l}20 \\
1 \\
1 \\
1 \\
1\end{array}$ & 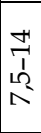 & 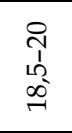 & $\begin{array}{l}\text { In } \\
\text { in } \\
\text { Ln }\end{array}$ & $\underset{T}{+}$ & $\begin{array}{l}10 \\
10 \\
1 \\
y\end{array}$ & $\begin{array}{l}1 \\
\infty \\
1 \\
1\end{array}$ & 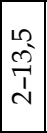 & $\left|\begin{array}{l}4 \\
7 \\
1 \\
10\end{array}\right|$ & ָ̃ & \begin{tabular}{|l} 
n. \\
1 \\
\end{tabular} & $\begin{array}{l}\infty \\
1 \\
\sim\end{array}$ & $\begin{array}{l}p \\
1 \\
1\end{array}$ & 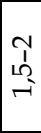 & $\begin{array}{l}\text { 옹 } \\
\text { à }\end{array}$ \\
\hline \multirow{4}{*}{ 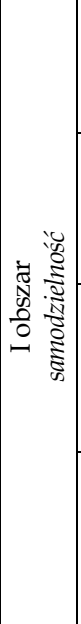 } & 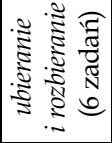 & $\begin{array}{l}p \\
1 \\
m\end{array}$ & $\begin{array}{l}\text { n' } \\
10 \\
1 \\
1\end{array}$ & 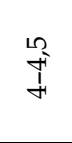 & 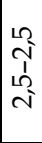 & $\mid \begin{array}{c}+1 \\
1 \\
\text { L } \\
\text { ले }\end{array}$ & $\begin{array}{l}12 \\
0 \\
1 \\
1 \\
\end{array}$ & $\begin{array}{l}12 \\
0 \\
1 \\
1 \\
N \\
v\end{array}$ & $\begin{array}{l}7 \\
1 \\
\\
-7 \\
\end{array}$ & 年 & $\begin{array}{l}p \\
1 \\
m\end{array}$ & $\stackrel{+1}{d}$ & I & $\stackrel{\text { IR }}{\underset{f}{+}}$ & $\stackrel{\sim}{\sim}$ & $\begin{array}{l}n \\
p \\
\text { pr }\end{array}$ \\
\hline & 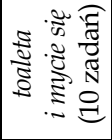 & $\begin{array}{l}10 \\
0 \\
1 \\
1 \\
0 \\
0\end{array}$ & $\stackrel{1}{1}$ & $\begin{array}{l}7 \\
1 \\
\text { L } \\
0\end{array}$ & $\begin{array}{l}12 \\
0 \\
1 \\
1 \\
i\end{array}$ & $\begin{array}{l}0 \\
1 \\
-1\end{array}$ & 1 & 1 & 1 & 1 & $\begin{array}{l}0 \\
1 \\
m\end{array}$ & $\stackrel{T}{1}$ & 1 & $\begin{array}{l}12 \\
\infty \\
1 \\
b\end{array}$ & $\begin{array}{l}0 \\
1 \\
1\end{array}$ & $\begin{array}{l}\stackrel{1}{1} \\
\text { م) }\end{array}$ \\
\hline & 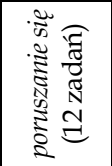 & $\begin{array}{l}0 \\
1 \\
1 \\
10 \\
10\end{array}$ & 공 & I & \begin{tabular}{l}
12 \\
0 \\
1 \\
1 \\
\multirow{1}{1}{} \\
+1
\end{tabular} & $\begin{array}{l}12 \\
10 \\
1 \\
10 \\
4 \\
4\end{array}$ & $\begin{array}{l}0 \\
1 \\
1 \\
10 \\
10\end{array}$ & 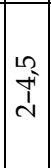 & 足 & $\left|\begin{array}{l}-1 \\
1 \\
2 \\
0 \\
0\end{array}\right|$ & 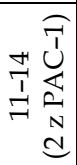 & $\begin{array}{l}a \\
1 \\
\infty\end{array}$ & \begin{tabular}{|l|}
12 \\
10 \\
1 \\
1
\end{tabular} & $\begin{array}{l}12 \\
\infty \\
1 \\
\infty\end{array}$ & 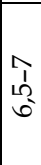 & $\begin{array}{l}0 \\
1 \\
0\end{array}$ \\
\hline & 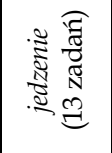 & $\begin{array}{l}\hat{1} \\
\text { م⿱⺈. }\end{array}$ & $\begin{array}{l}\circ \\
\text { 1 } \\
\text { L2 } \\
\sigma\end{array}$ & 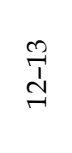 & $\begin{array}{l}12 \\
a_{1} \\
1 \\
\infty \\
\infty\end{array}$ & $\begin{array}{l}1 \\
1 \\
12 \\
6\end{array}$ & $\begin{array}{l}12 \\
0 \\
1 \\
1 \\
\text { م2 }\end{array}$ & $\begin{array}{l}0 \\
1 \\
1\end{array}$ & I & $\begin{array}{l}10 \\
10 \\
1 \\
+2 \\
0\end{array}$ & $\frac{m}{a}$ & 1 & $\left|\begin{array}{l}12 \\
\wedge \\
1 \\
12 \\
0\end{array}\right|$ & $\begin{array}{l}\stackrel{\infty}{7} \\
\stackrel{\sim}{\sim}\end{array}$ & $\hat{1}$ & 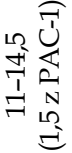 \\
\hline & 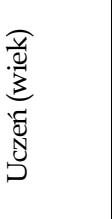 & 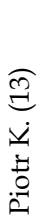 & 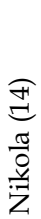 & 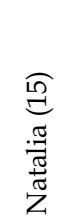 & 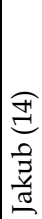 & 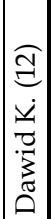 & 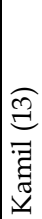 & 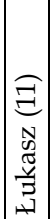 & 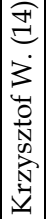 & 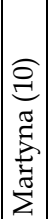 & 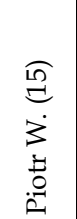 & 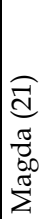 & 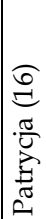 & 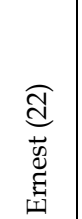 & 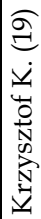 & 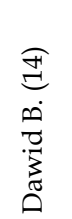 \\
\hline
\end{tabular}


Śledząc wartości liczbowe, można zauważyć, że w niektórych obszarach brakuje przyrostu umiejętności, w innych nie dokonano oceny, a czasami zaznaczono spadek liczby zaliczonych zadań. Takie wyniki diagnozy obrazują wyjątkowe trudności poszczególnych wychowanków lub pogorszenie ich kondycji związane ze współwystępującymi z niepełnosprawnością stanami chorobowymi. Zdaniem nauczycielek u niektórych podopiecznych zniżka umiejętności może wiązać się z wchodzeniem w okres dojrzewania, a co za tym idzie, występowaniem huśtawki nastroju, buntem czy apatią.

Porównując osiągnięcia uczniów w poszczególnych sferach, zauważa się, że najmniejsze postępy zostały zaznaczone w sferze „poruszanie się". Poza Piotrem W. i Nikolą, którzy chodzą niemal samodzielnie: z lekką asekuracją drugiej osoby - Nikola lub w pobliżu ściany, stołu - Piotr, pozostali diagnozowani podopieczni mają dużo słabsze możliwości $\mathrm{w}$ tym zakresie ze względu na orzeczoną głębszą postać mpd. Podobnie słabe postępy lub wręcz ich brak, a nawet regres, wystąpiły $\mathrm{w}$ dwóch pozostałych podobszarach: "toaleta i mycie się" oraz "ubieranie i rozbieranie się" - co można próbować wyjaśnić w podobny sposób. Nauczycielki zwracały też uwagę na doświadczenia uczniów związane z ciągłym wyręczaniem przez swoich rodziców. Niepokojące są tak słabe osiągnięcia szczególnie u tych dzieci i młodzieży, którzy - jak się wydaje - mają dość sprawne ręce. Podobnie wygląda sytuacja związana z podobszarem „sprawność manualna", co prawda w tym zakresie badani poczynili minimalne postępy, okazuje się jednak, że następuje słabe przeniesienie umiejętności nabytych w trakcie zajęć (z obszaru „,zajęcia”) na te z obszaru "samodzielność". Słaby transfer aktywności związanych z zabawą czy zadaniami "szkolnymi” na samodzielność $w$ ubieraniu, rozbieraniu, myciu się i korzystaniu $z$ toalety, a także w spożywaniu posiłków, u tych dzieci i młodzieży z głęboką niepełnosprawnością intelektualną, którzy mają zachowaną pewną sprawność manualną, może niepokoić i z pewnością wymaga większej współpracy ze środowiskiem rodzinnym, w celu kontynuowania wymagań stawianych w ośrodku. 
Co prawda w podobszarze ,jedzenie” wszystkie dzieci i młodzież poczynili większe lub mniejsze postępy, jednak argumentem wskazującym na specyfikę tej sfery życia jest motywacja do spożywania posiłków, która w wielu przypadkach rozpatrywanych uczestników zajęć wiąże się z doznaniami przyjemności i radości.

W odniesieniu do obszaru „komunikacja”, uczestnicy zespołów rewalidacyjno-wychowawczych poczynili duże postępy szczególnie w zakresie wyrażania siebie („od"). Nadawanie komunikatów (od siebie) świadczy o osiągnięciu przez niemal wszystkich badanych rozumienia stałości przedmiotu oraz swojej roli $\mathrm{w}$ diadzie komunikacyjnej. Brak mowy czynnej u większości badanych stanowi czynnik ograniczający porozumiewanie się, jednak włączenie do edukacji alternatywnych i wspomagających metod komunikacji powiększyło ich możliwości porozumiewania się. Tylko 2 dziewczyny spośród 15 ocenianych dzieci i młodzieży werbalizują w ograniczonym zakresie: Natalia wypowiada wiele słów, a nawet wyrażeń i prostych zdań, jednak zwykle na prośbę lub z podpowiedzią, z kolei Nikola ma w swoim repertuarze tylko kilka słów, którymi operuje spontanicznie. Inne kanały nadawania komunikatów - wokalizacja, mowa ciała, wyraz oczu oraz gesty stanowią o potencjale komunikacyjnym grupy.

Największe rezultaty odnotowane zostały w obszarze „uspołecznienie", który wiąże się z osiąganiem kolejno następujących zachowań: skupienie uwagi, wyciąganie rąk, uśmiechanie się, reagowanie głosem i ruchem (kręcenie się) po dostrzeżeniu innej osoby, rozpoznawanie najbliższych osób, wykazywanie zainteresowania obcymi i śledzenie ich ruchów, odpowiadanie na ekspresję twarzy, np. uśmiechem, klaskaniem w ręce, zwracanie na siebie uwagi poprzez hałas, oczekiwanie aprobaty za dobre zachowanie, staranie się by rozśmieszyć innych, okazywanie uczuć, przyglądanie się w lustrze, uznawanie posiadanych rzeczy jako własnych, pokazywanie i podawanie przedmiotów, machanie ręką na pożegnanie, zabawa $\mathrm{z}$ innymi bez współdziałania, liczenie się z pragnieniami innych, podnoszenie i niesienie przedmiotów na 
żądanie, oglądanie z zadowoleniem obrazków w książce, wyczekiwanie na swój moment i włączanie się na czas, pomoc w prostych zajęciach domowych. Większość z wymienionych zadań z Inwentarza PPAC Gunzburga nie tylko zostało oznaczonych jako sfera aktualnego rozwoju u badanych uczniów, ale to właśnie te i podobne zachowania można było zaobserwować na nagraniach zajęć oraz bezpośrednio w trakcie uczestniczenia lekcjach. Podobnie podsumowywały osiągnięcia swoich wychowanków nauczycielki w trakcie wywiadu. Wymienione zachowania wskazują na integrację zespołu oraz znaczenie grupy w uczeniu się przez naśladowanie, w rozumieniu siebie wśród innych jako ważnego i aktywnego podmiotu, ale też liczenie się z obecnością i znaczeniem kolegów i koleżanek.

Podobną wartość można przypisać działaniom ocenianym w podobszarze „zręczność”, które polegają na kontroli motoryki dużej i małej: usiłowanie sięgnięcia po przedmiot, manipulowanie przedmiotami, zdobywanie przedmiotu przez pochylenie się $\mathrm{ku}$ niemu, rzucanie przedmiotów na podłogę, spoglądanie $\mathrm{w}$ stronę upadających lub toczących się przedmiotów, ustawianie w porządku sześcianów lub klocków, kopnięcie piłki bez przewrócenia się, rzucanie piłki bez utraty równowagi, podnoszenie przedmiotów z podłogi bez podpierania się, skakanie na obu nogach, otwieranie drzwi z zamkiem automatycznym, wchodzenie i stawanie na krześle, samodzielne siadanie przy stole, otwieranie i zamykanie pudełka z pokrywką, zeskakiwanie obiema stopami z najniższego schodka, utrzymywanie się na jednej nodze przez krótki czas. Większość z tych zadań wiąże się ze sprawnością motoryki dużej i małej, skoro jednostka nie porusza się - nie chodzi, nie raczkuje - to trudno jest jej wykonać wiele z tych zadań. Jednak te, które wynikają z ciekawości poznawczej i mogą zostać zrealizowanie w pozycji siedzącej, okazują się być możliwe do zaliczenia. Wiele z nich należy do serii zadań wykonywanych na zajęciach prowadzonych metodą nauczania kierowanego.

Należy dodać, że kilkoro uczestników zajęć potrafiło wykonać pojedyncze zadania w niektórych obszarach spoza skali PPAC, stąd 
zapis, że punktacja jest podwyższona o zadania wykonane z Inwentarza PAC-1.

Podsumowując przeprowadzoną analizę, można wyciągnąć pewne (ograniczone ze względu na nieliczną próbę) konkluzje w odniesieniu do postawionego celu i problemu badawczego. Codzienne stosowanie metody nauczania kierowanego $\mathrm{w}$ zajęciach rewalidacyjno-wychowawczych organizowanych dla dzieci i młodzieży z głęboką niepełnosprawnością intelektualną przynosi korzystne efekty. Obszarami, w których zauważa się najwięcej postępów w rozwoju, są uspołecznienie i komunikacja. Natomiast w zakresie samodzielności w poruszaniu się, w ubieraniu i rozbieraniu się, spożywaniu posiłków oraz w czynnościach związanych $\mathrm{z}$ toaletą i higieną, $\mathrm{u}$ wielu uczniów nie odnotowano znaczących postępów. Wyjaśnień należy poszukiwać w nadopiekuńczości rodziców, ale także w szczególnie obciążonym funkcjonowaniu psychoruchowym tych osób (cięższe postaci mpd). Zastanawiający jest też słaby transfer umiejętności manualnych i kontroli ruchowej w zakresie motoryki małej i dużej nabytych w trakcie zajęć na aktywność związaną z samoobsługą. Być może ma to związek, poza oczywistą słabą sprawnością ruchową, z ograniczonymi możliwościami generalizacji wynikającymi z niepełnosprawności intelektualnej, choć fakt wyręczania w codziennych czynnościach przez rodziców, o czym już wspomniałam, może mieć także niebagatelne znaczenie.

Metoda nauczania kierowanego potwierdza więc swoje zastosowanie $\mathrm{w}$ stymulowaniu rozwoju społecznego dzieci i młodzieży z głęboką wieloraką niepełnosprawnością, nie należy jej jednak utożsamiać jedynie $\mathrm{z}$ oddziaływaniem rehabilitacyjnym na sferę motoryki dużej i małej i porównywać z metodami rehabilitacji ruchowej, takimi jak metoda Vojty, Bobathów czy Kabata. Zasady systemu nauczania kierowanego oraz jego metodyka (oparte na podstawach filozoficznych i naukowych) sprzyjają nabywaniu wielu umiejętności społecznych i komunikacyjnych, które z pewnością stanowią zręby podmiotowości i autonomii badanych osób. 


\section{Bibliografia}

Anttila H., Suoranta J., Malmivaara A., Mäkelä M., Autti-Rämö I., Effectiveness of physiotherapy and conductive education interventions in children with cerebral palsy: a focused review, "American Journal of Physical Medicine \& Rehabilitation" 2008, t. 87, nr 6.

Apanowicz J., Metodologia ogólna, Bernardinum, Gdynia 2002.

Chrzanowska I., Pedagogika specjalna. Od tradycji do wspótczesności, Oficyna Wydawnicza „Impuls”, Kraków 2015.

Cytowska B., Drzazga A., Znaczenie $i$ wykorzystanie komunikacji wspomagającej $i$ alternatywnej (AAC) w porozumiewaniu się z osobami z głęboka niepetnosprawnościa intelektualna, [w:] Dzieci o specjalnych potrzebach komunikacyjnych. Diagnoza - edukacja - terapia, red. B. Winczura, Oficyna Wydawnicza „Impuls”, Kraków 2013.

Forrai J., History of a Special Healing Method for Motordisordered Children: Conductive Education, "Communicationes de Historia Artis Medicinae", Suplement: 200-2001, 2007.

Fröhlich A., Stymulacja od podstaw. Jak stymulować rozwój osób głęboko wielorako niepetnosprawnych, WSiP, Warszawa 1998.

Jankiewicz A., Skrypnik D., Skrypnik K., Głęboka niepełnosprawność intelektualna a rozwój emocjonalno-społeczny i motoryczny, „Psychiatria” 2014, tom 11, nr 4.

Kościelska M., Oblicza upośledzenia, PWN, Warszawa 1998.

Pilch T., Bauman T., Zasady badań pedagogicznych. Strategie ilościowe i jakościowe, Wydawnictwo Żak, Warszawa 2001.

Rozporządzenie Ministra Edukacji Narodowej z dnia 23 kwietnia 2013 r. w sprawie warunków i sposobu organizowania zajęć rewalidacyjno-wychowawczych dla dzieci i młodzieży z upośledzeniem umysłowym w stopniu głębokim (Dz.U. z 7 maja 2013, poz. 529).

Sztumski J., Wstęp do metod i technik badań społecznych, Wydawnictwo Śląsk, Katowice 2005.

Topolski J., Problemy metodologiczne badań wsi, [w:] Badania empiryczne w socjologii, tom II, red. M. Malikowski, M. Niezgoda, Tyczyn 1997.

Witkowski T., Podręcznik do Inwentarza PPAC H.C. Gunzburga do oceny postępu w rozwoju społecznym (osób z upośledzeniem umystowym), COMPWZ MEN, Warszawa 1988.

\section{Źródła internetowe}

Beck F., Remembering András Pető, 2nd International Conference for Theory and Practice in Education,http://www.tsadkadima.org.il/_Uploads/dbsAttached Files/Remebering_Peto(3).pdf [20.05.2016].

Darrah J., Watkins B., Chen L., Bonin C., Effects of Conductive Education Intervention for Children with a Diagnosis of Cerebral Palsy, An AACPDM Evidence Report; http://www.aacpdm.org/UserFiles/file/conductive-education.pdf [20.05.2016]. 
Gegenwarth T. (ed.), Handbook Conductive Education. Together, Constructive, Conductive - Adult learners in Complex Rehabilitation, European Association of Conductive Education and Professional Practice (ECA), 2012, http://www.movewalk.se/ Portals/0/Handbook_Grundtvig_Final\%20Version.pdf [30.05.2016].

Wądołowska B., Kierowane nauczanie - edukacyjne rozwiazanie problemu medycznego, „BIULETYN SIECI MPD”, nr 4; http://www.spdn.pl/Biuletyny,a,32.html [10.05.2016].

Zhang Z., Bowens A., Bennet S., Effectiveness of conductive education for cerebral palsy, "Evidence Based Review" 2003, www.Conductive Education for Cerebral Palsy (PDF 292K) - October 2003 (1).pdf [10.05.2016]. 